\title{
Translating Circumstantial Clause of Arabic into Malay
}

\author{
Azman Che Mat ${ }^{1}$, Ahmad Marzuki Nazuki Yaakub ${ }^{1} \&$ Nurhafizah Ahmad Tajuddin ${ }^{2}$ \\ ${ }^{1}$ Academy of Language Studies, Universiti Teknologi MARA (UiTM) Dungun, Terengganu, Malaysia \\ ${ }^{2}$ Academy of Language Studies, Universiti Teknologi MARA (UiTM) Machang, Kelantan, Malaysia \\ Correspondence: Azman Che Mat, Academy of Language Studies, Universiti Teknologi MARA (UiTM), \\ Dungun Campus, 23000 Dungun, Terengganu, Malaysia. E-mail: azman531@tganu.uitm.edu.my
}

Received: March 11, 2014 Accepted: April 24, 2014 Online Published: June 25, 2014

doi:10.5539/ass.v10n13p72 URL: http://dx.doi.org/10.5539/ass.v10n13p72

\begin{abstract}
This paper aims to examine the function of circumstantial clause of Arabic for its translation into Malay. Circumstantial clause is among functional syntax in Arabic sentence structure. It is formed from the words or phrase in the sentence. This pattern does not seem to exist in the Malay grammar. In such circumstances, there is the difficulty to understand the meaning contained in a sentence correctly. Descriptive approach was used to analyze the circumstantial clause in Arabic. Comparative analysis is carried out on selected data of Arabic language with its translation in Malay. It is expected that there exist a need to understand the differences of these patterns in the work of the Arabic translation into Malay language.
\end{abstract}

\section{Introduction}

The study of translation on Arabic and Malay is significant and has been recognized in Malaysia. Azman and Ismail (2010) indicated there are ongoing studies at the masters and $\mathrm{PhD}$ level in Malay and Arabic language which has the potential to develop more translation programs in the future. The increasing awareness of the important of translation has led to an active research in several public universities in Malaysia. The number of articles and research papers presented in conferences has shown significant increase in Arabic-Malay translation as compared to the past 10 years.

Learning Arabic language is a must for being a Muslim, for that matter and in most cases; Arabic is being learnt and acquired by those who want to join this religion (Mohammed, 2012). Those who want to understand the Arabic language should learn its grammar (Khalilullah, 2012: 10). As the grammar or specifically known as syntax is among critical parts of the Arabic language, it scrutinizes on the structure aspects of a sentence. Syntax is the linguistic domain which is often given priority in the Arabic language education even for non-native speaker. This is due to the many elements of the language expressed in the form of a perfect sentence. Therefore attention to the syntax became so important and meaningful which includes methods of constructing sentences, types of sentences and grammatical sentences in a particular language.

Major aims of each language are the same, but such language will be necessarily either completely or partially different from another language. Thus one language can be partially similar to another language but not necessarily completely similar to that or this language. For instance, Arabic and Malay languages are originally different from one another. More precisely, compare the structure of sentence system in the two languages. Basically, they both have the same type of sentence such as nominal sentence (NS), but another sentence structure in Arabic namely verbal sentence (VS) is entirely different from Malay. For that reason, translation of Arabic especially for verbal sentence and its components face difficulties in finding an equivalence sentence in Malay. These difficulties might be due to the nature of language (Arabic) structure is not found in another language (Malay) structure.

As Catford (1996) mentioned, the translation becomes impossible when the functional meaning of the situation in the context of the source text failed to find matches in the target language. This phenomenon exists because a matching translation occurs only when the source language and target language characterized in that situation has relevant functions. Thus, translation difficulties arise when the translator failed to find a match for an object or expression that did not exist in the target language. Leonardi (2000) also added that the concept of equivalence is among the most complicated and full of controversies in the theory of translation. This is due to languages differ with respect to sentence arrangement or syntax (al-Hamdalla, 1998; cf. al-Darawish, 1983). This 
present article is intended to shed a light on translation of syntactical aspect of Arabic language into Malay, one among languages used in Asian region.

\section{Overview on Sentence Structure of Arabic and Malay}

In this article, the both language systems are not syntactically contrasted in detail that is showing only the basic differences and similarities for providing clear picture of the main objective of the study. As mentioned earlier, in Arabic syntax, sentence is divided into two structures, namely nominal sentence (NS)and verbal sentence (VS) (see: Ibn Fāris 395 H, Ibn Hishām708-761 H, Ibn ' Aqīl 698-769 H, al-Maylānī 811 H, al-Rājị̣ī 1971 \& Maghālasah 1993). Based on these structures, transformation is applied by the addition of a functional word or phrase. Even for simple sentence, several patterns and expansion can be generated into other forms of grammatical sentences of infinite abundance. Ghazala (2008) mentioned that nominal sentence requires no verb at any kind and consist of two nouns, while verbal sentence requires verb and noun in a sentence.

Based on syntactical account, NS can be explained as the following 'SP' rule [S=Subject, $\mathrm{P}=$ Predicate], for example: هحمد is (noun). The pronoun is subject and the noun is predicate. Subject in NS can be any noun and pronoun with their varieties. While VS in Arabic is constructed based on 'VS' rule [V=Verb, S=Subject] such as: قام محمد. The VS of the example consisted of verb محمد and noun . Commonly, such sentence that beginning with verb will be identified as VS.

Malay language has only nominal sentence with four patterns (Nik Safiah et al., 2008). Moreover, it may have seven patterns of sentence based on the position of subject and predicate (Halimah, 2005). For instance, SP rule for Dia Muhammad is constructed from subject 'Dia' and predicate 'Muhammad.' Any sentence with verbal structure will be classified as predicate such as Muhammad berdiri, whereas 'Muhammad' is subject and verb 'berdiri' is predicate.

The use of SP and VS rules is intended to describe Arabic sentence to it counterpart, however is not yet completed. It is because what this paper's main focus is an additional part of Arabic sentence namely complements. Arabic has many complements in sentence such as cognate phrase, place adverbial, time adverbial, and adverbial accusative of specification, adverbial accusative of cause or reason and circumstantial clause. These detail categories have proven even most languages are likely to have equivalents for the more general verbs of speech such as say and speak, but many may not have equivalents for the more specific ones (Baker, 1996: 18).

To understand Arabic and Malay sentences, the following comparison briefly highlighted the similarity and difference of both languages:

\section{Similar: Arabic: هو محمد [SP] He is Muhammad.}

Malay: Dia Muhammad [SP]

The above sentences have equivalence one word to one word based on SP rule. As g equivalence to 'dia' and محمد equivalence to 'Muhammad.' Therefore this SP rule has similarity and may not be a problem for understanding and translating the sentence.

2. Similar: Arabic: محمد يذهب إلى الجامعة[SP-COM] Muhammad goes to university.

Malay: Muhammad pergi ke university [SP-COM]

Again, equivalence is a matter of meaning and syntactical account for these two examples. The main principal of Arabic and Malay based in SP rule remains in. But needless to say, the Arabic sentence of the example here is seldom used in Arabic discourse unless for rhetorical meaning. For instance, foregrounding of noun in VS above is to demonstrate imperative and priority of the subject.

3. Different: Arabic: يعمل محمد الو اجب المنزلي [VS-COM] Muhammad works on assignment.

Malay: Muhammad membuat tugasan [SP-COM]

As mentioned previously, Arabic has SV rule for sentence construction as shown above. While as Malay's sentence construction yet holds SP rule to render this sentence. Therefore in Malay translation, SP rule is applied to the sentence.

What are needed to be highlighted here are complements (COM) that was attached in both; sentence (2) and sentence (3) above. Even from these examples, translator may not find crucial challenge to provide a good translation because COM from the examples are prepositional clause and object respectively. But this is not to say that both COMs are always easily translated into Malay. There is a common COM in Arabic sentence namely circumstantial clause which has moved this study into translation approach. 
From the point of view of translation, the circumstantial clause can be positioned as complementary in the Arabic sentence. Indeed it is crucial for translator to master the knowledge of the circumstantial clause as one of accusative marker patterns before embarking into the translation process. This study will discuss the technique in translating one of the patterns of accusative marker, named circumstantial clause or hāal (حال) in Arabic when translating the al-Quran.

\section{Translation of Circumstantial Clause}

$H \bar{a} l$ is a derivative noun, complementary, accusative, which demonstrate a 'state' that happened and the answer to the question 'how' (al-Kawāri, 2008). Meanwhile, al-Harami (2005) and Ibn al-Anbāri (1997) gave a very brief definition, namely, the condition of subject or object. This optional status as fadla 'extra' or 'surplus' parts of sentence rather than part of kernel or core predication. The fact is they are very common in both spoken and written discourse (Karin, 2005: 283).

It's significant to examine how this pattern is translated into Malay from selected verses of sura al-Baqara. The translation was carried out by respectful scholar, Sheikh Abdullah Basmeih (1996) and his work was well accepted among Muslim in Malaysia for it authority and recognition by Ministry of Islamic Department. To identify circumstantial clause of Arabic sentence from the data, Sayyid Tantawi (1998) works were referred.

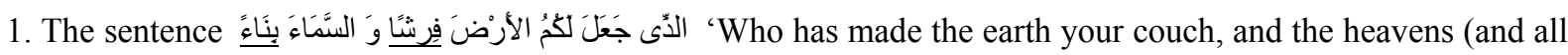

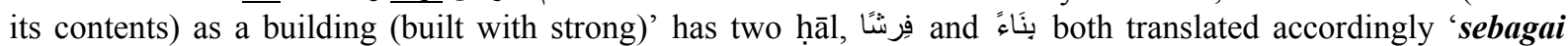
hamparan' and 'sebagai bangunan.' This pattern in the above sentence using derivatives, from the root فرش (spread) and بنى (build), one of the derivation of the verb. Translator uses "sebagai" to clarify the meaning of the pattern of things. According to Malay grammar, the word "sebagai" is a variation of the root word "bagai" and it means 'so' and 'be' (Teuku \& Baharuddin, 2000: 84). For example, 'Ali bekerja sebagai pelayan' (Ali worked in a restaurant as a waiter) and 'Saya melantik awak sebagai pembantu saya' (I appoint you as my assistant). In this context, it can be seen that the use of "sebagai" is appropriate to form a compound sentence. Based on the translation above, it can be broken down into two phrases: 1. God made the earth, 2. Earth is a stretch. By using the word "sebagai" the two phrases are combined into one sentence only. Based on this explanation, it can be said that the use of this pattern can be rendered in two phrases and combined with the use of the word "sebagai."

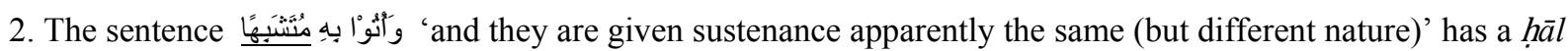

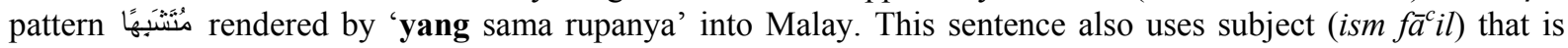
derived from a verb shabbaha شبه (resemble) the pattern of things. The phrase 'yang sama rupanya' translates the circumstantial clause in the Malay language. The word 'yang' is used as a relative conjunction stakes that aims to connect the main clause with a small clause (Nik Safiah Karim et al., 2008: 241). In the Malay language such sentences using conjunctions is, 'Budak lelaki yang saya jumpa semalam adalah pelajar baru' (Boy, I found yesterday was a new student) and 'Saya suka warna yang terang' (I love bright colors). By looking at the translation above, the sentence can be broken into two clauses, namely: 1 . They are given things, 2 . The same provision. So it can be explained that the use of circumstantial clause can be translated accordingly to a formula based on the combination of the two clauses in Malay and the use of relative conjunctions "yang."

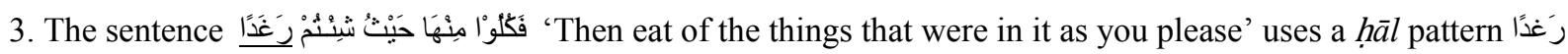
rendered by 'dengan sepuas-puasnya' into Malay. This sentence uses derivative word رغدا 'رغا '(free, easy), which is one of derivation for verb رغد. In this sentence the translator uses preposition 'dengan' to describe the coupled, joined, way, use, and the comparison (Nik Safiah Karim 2008: 266; Teuku Iskandar \& Baharuddin 2000: 289). In Malay, the use of 'dengan' has broad semantic implication to explain the way or use such as, 1. 'Saya melukis dengan pensil' (I draw by pen), to explain coupled or joined, 2. 'Saya pergi dengan Ahmad' (I go with Ahmad), or to compare, 3. 'Saya datang dengan semangat berkobar-kobar' (I come with a blazing spirit). Therefore, circumstacial clause can be rendered by using preposition 'dengan' whether to explain the way or use, coupled or joined and to compare the level of attitude.

\section{Conclusion}

This study provides an initial overview of the principles of translating circumstantial clause in Arabic. Although this study is not pedagogically oriented, it may have in certain degree, pedagogical implications for foreign language teachers, learners, syllabus designers, test makers as well as textbook writers. On the implications of the Arabic language education, the knowledge about the principles of translation of syntactic patterns can help to explain the function of it in the context by understanding the native language of students. Moreover, it may help the teacher to diagnose and remedy the difficulties the students may encounter. This is because the learners of 
Arabic language think that grammar rules should be explained and that grammar should not be thought explicitly (Azman \& Goh, 2010a).

Previous studies indicated the most challenges encountered by Arabic learners are grammar rules (Azman \& Goh, 2010b; Azani et al., 2012). For instance, VS and NS are among the repeated mistakes including genus, number and word order. This study may in various ways help the language teachers and learners and translators in identifying the circumstantial clause forms and structures that have different functions. In other hand, this study may help students of Arabic and translators to understand the major similarities and differences between Arabic and Malay.

In short, it is meaningful to comprehend the function of circumstantial clause for translation proposes. Importantly, the use of circumstantial clause closely related to VS construction. From this study, translation of circumstantial clause has difference technique with regard to these principles:

1. Translator can use auxiliary 'sebagai' for Arabic sentence which refers to the condition or state of a change to other conditions (see example below and appendixes: 1).

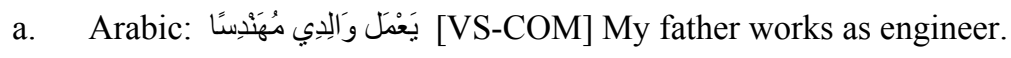

Malay: Bapa saya bekerja sebagai jurutera.

2. Translator may use conjunctions 'yang' for Arabic sentence to explain the additional information for the main clause (see example below and appendixes: 2).

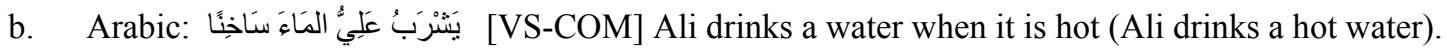

Malay: Ali minum air yang panas [VS-COM]

The source sentence is different to target sentence, the word ساخنا is to explain the condition of the water as an object, not its attribute. Therefore, in translation, particle 'yang' is jointed between 'air' and 'bersih.' The phrase 'yang bersih' is consisted of conjunction particle (yang) and adjective (bersih).

3. Translator may use preposition 'dengan' for Arabic sentence to explain the additional information for the main clause (see example below and appendixes: 3 ).

c. Arabic: جَاءَ أحْدَ مَانَثِيًا [VS-COM] Muhammad comes walkingly.

Malay: Ahmad datang dengan berjalan kaki [SV-COM]

The Arabic word مانشيا explains the 'how' Ahmad as a subject comes. It is rendered to 'dengan berjalan kaki' in Malay. The phrase 'dengan berjalan kaki' is consisted of prepositon (dengan) and verb + noun (berjalan+kaki).

After the discussion of the Malay translation of circumstantial clause principles, it is concluded that the Malay translation of circumstantial clause is successful not only in form, but also in meaning as the Malay translation of circumstantial clause is consistently practiced by Malay prominent translator. Even so, these principles are yet to be improved and refined by conducting a more detailed study, especially involving different grammar rules of Arabic and Malay. The general principles can be founded on continues study for translation and education purpose. Therefore, in the translation practice, especially grammar structures, it is necessary to consider the factor including functional equivalence.

\section{Acknowledgements}

The research is financed by the Higher Learning Ministry (HLM) of Malaysia under the Fundamental Research Grant Scheme (FRGS) for a period of two years beginning in June 2011 to July 2013. Heartfelt appreciation and thanks from us to HLM, Research Management Institute (RMI), Universiti Teknologi MARA on the support and trust. We are indebted to all individuals in the study for their support and encourage by all means.

\section{References}

al-Ba ${ }^{\mathrm{C}}$ labaki, R. (1995). al-Mawrid. Beirut: Dār al-Malāyīn.

Alduais, A. M. S. (2012). Simple sentence structure of standard Arabic language and standard English language: A contrastive study. International Journal of Linguistics, 4(4), 500-54. http://dx.doi.org/10.5296/ ijl.v4i4.2621

al-Hamdalla, R. (1989). Problems and approaches to translation with special reference to Arabic. Language \& Translation, 10, 23-28.

al-Haramiy, U. I. I. (2005). Al-muḥarrar fi al-naḥw. Kaherah: Dār al-Salām.

al-Kawari, K. (2008). Al-wasìtfi al-naḥw. Beirut: Dar Ibn Ḥazm. 
Baker, M. (2001). In other words: A course book on translation. London and New York: Taylor \& Francis Group.

Basmeih, A. (1996). Tafsir pimpinan ar-Rahman kepada pengertian al-Quran. Kuala Lumpur: JabatanPerdana Menteri Malaysia.

cAbbas, H. (1975b). Al-naḥw al-wāfiy. Kaherah: Dār al-Ma āârif.

Catford, J. C. (1996). Teori linguistik bagi penterjemahan. Translated by Uma A/P Iyavoo \& Koh Chung Gaik. Kuala Lumpur: Dewan Bahasa dan Pustaka.

Gaber, J. M. (2005). A Textbook of translation: concepts, methods \& practice. Emirates: University book House.

Ghazala, H. (2008). Translation as problems and solutions. Beirut: Dār al- ${ }^{c} \mathrm{ilm}$ lilmalāyīn.

Ibn al-Anbāri, 'Abd al-Rahmān bin Muhammad bin ${ }^{c}$ Abdullah. (1997). Asrār al-'arabiyyah. Beirut: Dār al-Kutub al-'Ilmiyyah.

Ibn 'Aqīl, Bahā’ al-Dīn 'Abdullah. (2001). Sharh ibn ${ }^{c}$ Aqül cala alfiyah al-Imam Ibn Mālik. Beirut: Dār Al-fikr.

Ibn Hishām, Jamāluddin ${ }^{c}$ Abdullah bin Yusof. (1972). Mughni al-labīb ${ }^{c}$ an kutub al-a ārīb. Beirūt: Dār al-Fikr.

Iskandar, T., \& Zainal, B. (2000). Kamus Dewan Edisi Keempat. Kuala Lumpur: Dewan Bahasa dan Pustaka.

Karin, C. R. (2005). A reference grammar of modern standard Arabic. USA: Cambridge University Press.

Khalilullah, M. (2012). Media pembelajaran bahasa Arab. Yogyakarta: Aswaja Press Indo.

Leornardi, V. (2000). Equivalence in translation between myth and reality. Retrieved from http://accurapid.com/journal/14equiv.htm

Maghālasah, M. H. (1993). Al-naḥ̂w al-shāfì. Beirūt: Mu'assasat al-Risālah.

Mat, A. C., \& Muhammad, I. (2010). Brief history of translation experience in Malaysia: A case of ArabicMalay's translation. Studies in Literature and Language, 1(1), 57-61.

Mat, A. C., \& Soon, G. Y. (2010a). Grammar in the classroom: Students' expectations and reality: the case of Arabic and Mandarin. Novitas-ROYAL (Research on Youth and Language), 4(1), 51-63.

Mat, A. C., \& Soon, G. Y. (2010b). Situasi pembelajaran bahasa asing di institut pengajian tinggi: Perbandingan antara bahasa Arab, bahasa Mandarin dan bahasa Perancis. AJTLHE, 2(2), 9-21.

Nik Safiah Karim, M., Onn, H., \& Hamid, A. (2008). Tatabahasa Dewan:edisi baharu. Kuala Lumpur: Dewan Bahasa dan Pustaka.

Sayyid al-Ṭan āwi, M. (1998). Mucjam ícrāb alfäz al-Qur'ān al-karìm. Beirut: Maktabah Lubnān.

Yaakub, A. I., Mat, A. C. \& Pa, M. T. (2012). Membina kemahiran pertuturan menerusi aktivitilakonan dalam pengajaran bahasa Arab. GEMA Online ${ }^{\circledR}$ Journal of Language Studies, 12(1), 325-337.

\section{Appendixes}

Appendixes: 1

\begin{tabular}{|c|c|c|}
\hline No. & Arabic Sentence & Translation \\
\hline 1 & 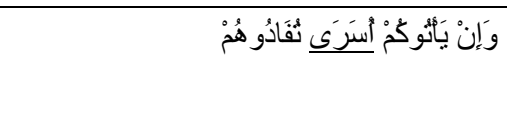 & $\begin{array}{l}\text { kalau mereka datang kepada kamu sebagai orang tawanan, kamu } \\
\text { tebus mereka; }\end{array}$ \\
\hline 2 & 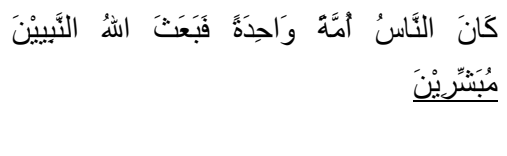 & $\begin{array}{l}\text { Pada mulanya manusia itu ialah umat yang satu (menurut ugama } \\
\text { Allah yang satu, tetapi setelah mereka berselisihan), maka Allah } \\
\text { mengutuskan nabi-nabi sebagai pemberi khabar gembira }\end{array}$ \\
\hline
\end{tabular}

Appendixes: 2

\begin{tabular}{|c|c|c|}
\hline No. & Arabic Sentence & Translation \\
\hline 1 & 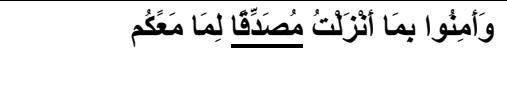 & $\begin{array}{l}\text { Dan berimanlah kamu dengan apa yang Aku turunkan (Al-Quran) } \\
\text { yang mengesahkan benarnya Kitab yang ada pada kamu }\end{array}$ \\
\hline 2 & 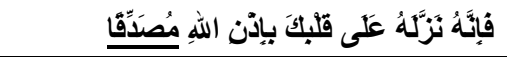 & kerana Jibril itu menurunkan Al-Quran ke dalam hatimu dengan izin \\
\hline
\end{tabular}


Allah, yang mengesahkan kebenaran

3

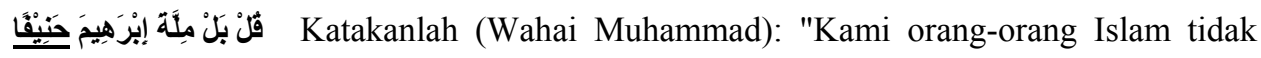
akan menurut apa yang kamu katakan itu) bahkan Kami mengikut ugama Nabi Ibrahim yang tetap di atas dasar Tauhid,

4 Wahai sekalian manusia! makanlah dari apa yang ada di bumi yang halal lagi baik,

Appendixes: 3

\begin{tabular}{|c|c|c|}
\hline No. & Arabic Sentence & tion \\
\hline 1 & وَادْخُلوا البَابَ سُجُجًَا & $\begin{array}{l}\text { dan masuklah kamu melalui pintunya dengan tunduk (merendah } \\
\text { diri); }\end{array}$ \\
\hline 2 & 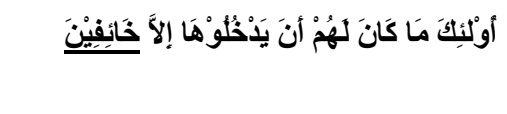 & $\begin{array}{l}\text { Orang-orang yang demikian, tidak sepatunya masuk ke Dalam } \\
\text { masjidmasjid itu melainkan dengan rasa penuh hormat dan takut }\end{array}$ \\
\hline 3 & 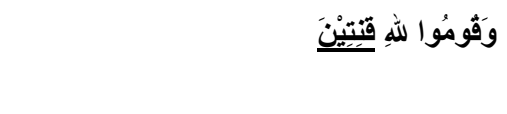 & $\begin{array}{l}\text { dan berdirilah kerana Allah (dalam sembahyang kamu) dengan taat } \\
\text { dan khusyuk. }\end{array}$ \\
\hline 4 & 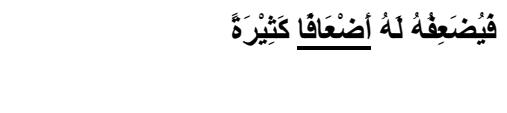 & $\begin{array}{l}\text { supaya Allah melipatgandakan balasannya dengan berganda-ganda } \\
\text { banyaknya }\end{array}$ \\
\hline 5 & 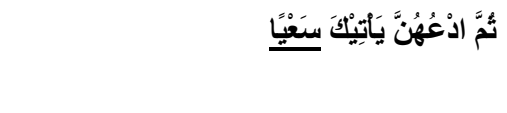 & $\begin{array}{l}\text { kemudian serulah burung-burung itu nescaya semuanya akan datang } \\
\text { kepadamu dengan segera. }\end{array}$ \\
\hline 6 & 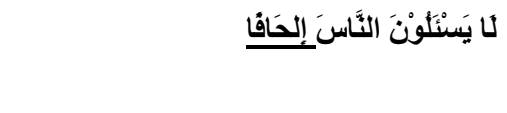 & $\begin{array}{l}\text { mereka tidak meminta kepada orang ramai dengan } \\
\text { mendesak-desak. }\end{array}$ \\
\hline 7 & 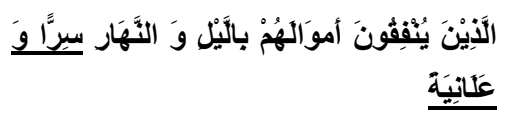 & $\begin{array}{l}\text { Orang-orang yang membelanjakan (mendermakan) hartanya pada } \\
\text { waktu malam dan siang, dengan cara sulit atau terbuka }\end{array}$ \\
\hline
\end{tabular}

\section{Copyrights}

Copyright for this article is retained by the author(s), with first publication rights granted to the journal.

This is an open-access article distributed under the terms and conditions of the Creative Commons Attribution license (http://creativecommons.org/licenses/by/3.0/). 